\title{
FUEL CONSUMPTION AND ENGINE LOAD FACTORS OF EQUIPMENT IN QUARRYING OF CRUSHED STONE
}

\author{
Mario Klanfar, Tomislav Korman, Trpimir Kujundžić
}

Original scientific paper

Load factors, defined as portion of utilized engine power, are used in estimation of the diesel mining equipment fuel consumption. Every type of equipment is involved in the specific work operation, common in quarrying of crushed stone. Furthermore, load factors are specific for the equipment type and their application/operating conditions. Based on the mining company's empirical data on fuel consumption, load factors of the main equipment in quarrying of crushed stone are determined in this paper. This includes bulldozer, backhoe excavators, wheel loaders, trucks, blasthole drill, mobile crushing and screening plants, and mobile belt conveyor. With an assumption of similar operating conditions, those factors can be considered as characteristic for small quarries of crushed stone, but also for mining on other surface pits, depending on the specific equipment application. The obtained load factors are compared to the available data from other sources in order to verify the results and establish the appropriate procedure for assessment of unknown load factors in different operating conditions.

Keywords: crushed stone; diesel drive; fuel consumption; load factor; mining equipment; quarrying

\section{Potrošnja goriva i koeficijenti opterećenja pogonskih motora mehanizacije pri eksploataciji tehničko-građevnog kamena}

Izvorni znanstveni članak

Koeficijenti opterećenja, definirani kao udio nazivne snage pogonskog motora angažirane pri radu, koriste se pri procjeni potrošnje goriva rudarske mehanizacije. Svaka vrsta mehanizacije koristi se u specifičnom radnom procesu pri eksploataciji tehničko-građevnog kamena. Koeficijenti opterećenja karakteristični su za vrstu stroja i radni proces/uvjete rada. Prema empirijskim podacima potrošnje goriva koncesionara, u ovome radu su određeni koeficijenti opterećenja pogonskih motora glavnih strojeva pri eksploataciji tehničko-građevnog kamena. Ovo uključuje dozer, bagere, utovarivače, kamione, bušaću garnituru, pokretna postrojenja za sitnjenje i klasiranje, te pokretni tračni transporter. S pretpostavkom sličnih radnih uvjeta, dobiveni koeficijenti opterećenja mogu se smatrati karakterističnima za male kopove tehničko-građevnog kamena, ali i ostale površinske kopove, zavisno o primjeni mehanizacije. Dobiveni koeficijenti opterećenja uspoređeni su s drugim izvorima radi verifikacije rezultata i određivanja pogodne procedure procjene nepoznatih koeficijenata opterećenja u nepoznatim radnim uvjetima.

Ključne riječi: dizel pogon; koeficijent opterećenja; potrošnja goriva; rudarstvo; tehničko-građevni kamen

\section{Introduction}

In the lack of empirical data on fuel consumption, a common practice is to estimate the latter based on the specific fuel consumption, engine load factor and rated engine power.

Specific fuel consumption is a mass of fuel spent per unit of time and unit of power, with an engine operating at full rated power. It is usually expressed in $\mathrm{kg} /(\mathrm{kW} \cdot \mathrm{h})$ and mainly depends on an engine type and efficiency. For diesel engines it ranges from 0,21 to $0,26 \mathrm{~kg} /(\mathrm{kW} \cdot \mathrm{h})$, where the lower values correspond to modern and lowaged engines, while the higher values correspond to old, technologically less efficient and worn out engines [1]. It also varies with engine size and power, since larger diesel engines have higher fuel efficiency [2]. The authors of the previous paper presented fuel consumption of several engines with the rated power between $1864 \mathrm{~kW}$ and 2722 $\mathrm{kW}$, operating at $100 \%$ load. The obtained data is herein converted into specific fuel consumption based on the usual diesel fuel density of $0,85 \mathrm{~kg} / \mathrm{l}$. In Fig. 1 it can be observed how it ranges between 0,2 and $0,208 \mathrm{~kg} /(\mathrm{kW} \cdot \mathrm{h})$, for given engine powers. Also, there is a decrease of $9 \times 10^{-6} \mathrm{~kg} /(\mathrm{kW} \cdot \mathrm{h})$ per $1 \mathrm{~kW}$.

Engine load factor is defined as a portion of the rated engine power that is utilized during work process. It is very specific to the equipment type and application/operating conditions, but independent on the equipment size and the rated engine power [3]. For cyclic equipment it can range from below 0,1 during idle operation to 1,0 during full power operation. The continuous equipment usually has a relatively constant load factor, since there is little variation in power demand during operation, as opposed to the cyclic equipment.

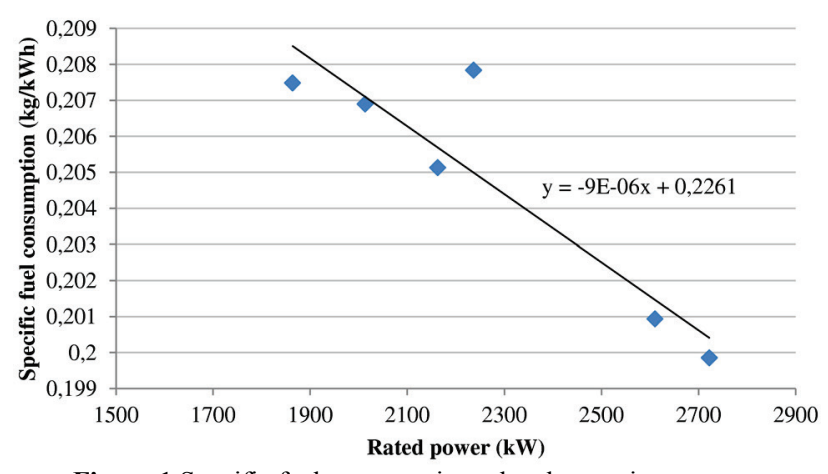

Figure 1 Specific fuel consumption related to engine power

Calculation of fuel consumption requires an average load factor across a cycle, or a longer period of operation. One can be estimated from a cycle character or calculated from the empirical data, obtained by measuring and monitoring the actual fuel consumption. Those calculated from empirical data can then be applied to the equipment of the same type and the application/operating conditions, but of different sizes and engine power.

The basic approach in estimating fuel consumption is to assume the specific fuel consumption according to the engine condition and type, then apply the rated engine power known from equipment specifications, and eventually define the load factor specifically for the equipment type and the application/operating conditions. 
Knowing these values, consumption can be calculated using the following equation [4]:

$q_{d}=P \cdot k_{o} \cdot s_{d}$

where: $P$ - rated engine power $(\mathrm{kW}), k_{o}$ - engine load factor, $s_{d}-$ specific fuel consumption $(\mathrm{kg} /(\mathrm{kW} \cdot \mathrm{h}))$.

\section{Research goals and method}

The main goal in this research is to obtain load factors for equipment used in quarrying of crushed stone. Factors were determined for equipment and operating conditions common in small quarries. They are based on five-year data on fuel consumption and can be considered characteristic for specific operating conditions, which are related to mentioned quarry type.

The other goal is to provide estimation of load factors in different operating conditions. Determined empirical factors were compared to the other sources, some of which contain description of operating conditions as main aspect that load factor depend upon. It considers that sources with highest correspondence to empirical data are the most convenient for estimation.

Fuel consumption data was collected from a mining company and averaged by the equipment type and model. The results were calculated back to load factors using transformation of Eq. (1). Knowing the quarrying process and application of equipment in company's quarries, factors are classified to matching operating conditions and compared to the other sources. Details on equipment usage, calculation of factors and data comparison are provided in the subsequent chapters.

\section{Fuel consumption and load factors overview}

Typical engine load factors are based on equipment type and application/operating conditions. They can be found in some literature on mining and construction equipment, but generally represent a rare topic and cover only a narrow span of equipment types. On the other hand, equipment manufacturers offer fuel consumption data related to a broad range of the specific equipment models $[5,6]$. This is useful but less versatile when dealing with sizing and selection of the equipment. Some other sources provide load-specific fuel consumption, which represents hourly consumption at operating load, reduced to engine power and expressed in $1 /(\mathrm{kW} \cdot \mathrm{h})$. The latter can be considered as the equivalent to the load factor, since it expresses consumption at operating load. It does not, however, provide means to account for differences in fuel density and engine efficiency during estimation of consumption. Mentioned data on load factors are available for the commonly used equipment like trucks, excavators, scrapers and dozers, but it is hardly found for hydraulic hammers, blasthole drills or mobile crushing plants, screening plants and belt conveyors. Therefore, it is useful to provide some insight into those factors and their span for this latter group of equipment, even if they are suitable for specific quarry type.

Several sources are used in this research in order to compare them with empirical data, and mutually. Tab. 1 and Tab. 2 show typical load factors for trucks and dozers after Kennedy [1]. They are classified into three groups of operating conditions: light, average and heavy, where single value is assigned for every group. Description of operating conditions is available, as a guideline for factor assessment. Tab. 3 and Tab. 4 show the general factors according to Day [7] and Chitkara [8]. In contrast to the first source, these only provide values simply classified into three groups, but without any detailed description.

The equipment handbooks by Caterpillar and Komatsu offer fuel consumption of specific equipment models, classified into three ranges of load conditions. Conditions are similarly described in both manuals and those applicable to quarries of crushed stone are summarized in Tab. 5. To present large amount of the data from this sources, fuel consumption ranges of every equipment model were divided by engine power in order to obtain load-specific consumption. An average value of the latter, for the same equipment type, is then assigned to the corresponding load condition range. The same procedure was done using the data from construction equipment catalogue by Đukan et al. [9], since it contains consumption and engine power for many models. Difference from other sources is that it provides single value as the average consumption across all load conditions (Tab. 6). Gransberg et al. [10] provides the explicitly specified load-specific consumptions, and thus no conversion is done in this case (Tab. 7). Both of the latter sources provide no details on operating conditions.

Table 1 Typical truck load factors according to Kennedy [1]

\begin{tabular}{|l|c|c|c|}
\hline \multirow{2}{*}{ Truck type } & \multicolumn{3}{|c|}{ Load factor* } \\
\cline { 2 - 4 } & Light & Average & Heavy \\
\hline Conventional rear dump & 0,25 & 0,35 & 0,50 \\
\hline Tractor-trailer & 0,35 & 0,50 & 0,65 \\
\hline Integral bottom dump & 0,25 & 0,35 & 0,50 \\
\hline $\begin{array}{l}\text { *Light: Considerable idle, loaded hauls on favourable grades and good } \\
\text { haulage roads }\end{array}$ \\
\hline $\begin{array}{l}\text { *Average: Normal idle, loaded hauls on adverse grades and good } \\
\text { haulage roads }\end{array}$ \\
\hline *Heavy: Minimum idle, loaded hauls on steep adverse grades \\
\hline
\end{tabular}

Table 2 Typical bulldozer load factors according to Kennedy [1]

\begin{tabular}{|l|c|c|c|}
\hline \multirow{2}{*}{ Dozer type } & \multicolumn{3}{|c|}{ Load factor* } \\
\cline { 2 - 4 } & Light & Average & Heavy \\
\hline Crawler & 0,45 & 0,60 & 0,75 \\
\hline Wheel & 0,45 & 0,60 & 0,80 \\
\hline *Light: Considerable idle or travel with no load \\
\hline *Average: Normal idle, normal production dozing, back track push \\
loading scrapers, steady shovel cleanup \\
\hline $\begin{array}{l}\text { *Heavy: Minimum idle and reverse travel, heavy production dozing, } \\
\text { chain and shuttle push loading scrapers, steady ripping }\end{array}$ \\
\hline
\end{tabular}

Table 3 Typical load factors for various equipment according to Day [7]

\begin{tabular}{|l|c|c|c|}
\hline \multirow{2}{*}{\multicolumn{1}{c|}{ Type of equipment }} & \multicolumn{3}{c|}{ Operating conditions } \\
\cline { 2 - 4 } & Excellent & Average & Severe \\
\hline Wheel-type, paved road & 0,25 & 0,30 & 0,40 \\
\hline Wheel-type, off highway & 0,50 & 0,55 & 0,60 \\
\hline Crawler-track type & 0,50 & 0,63 & 0,75 \\
\hline Power excavators & 0,50 & 0,55 & 0,60 \\
\hline
\end{tabular}

Table 4 Load factors in different operating conditions according to Chitkara [8]

\begin{tabular}{|c|c|c|c|}
\hline \multirow{2}{*}{} & \multicolumn{3}{|c|}{ Operating conditions } \\
\cline { 2 - 4 } & Favourable & Average & Unfavourable \\
\hline Bulldozer & 0,60 & 0,70 & 0,80 \\
\hline Wheel loader & 0,35 & 0,45 & 0,55 \\
\hline Truck & 0,25 & 0,35 & 0,45 \\
\hline
\end{tabular}


Table 5 Operating conditions and load-specific fuel consumption according to Caterpillar [6] and Komatsu [5]

\begin{tabular}{|c|c|c|c|}
\hline & Low & Medium & High \\
\hline \multirow[t]{2}{*}{ 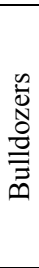 } & $\begin{array}{l}\text { Stockpile operation }{ }^{1} \\
\text { Intermittent full throttle operation }^{1} \\
\text { Considerable idling or travel with no load } \\
\text { Spreading work } \\
\text { Considerable idling or travel with no } \\
\text { load }^{2}\end{array}$ & $\begin{array}{l}\text { Dozing in clays, sands, gravels } \\
\text { Land claring }^{1} \\
\text { Some idling and some travel with no load } \\
\text { Digging, dozing, ripping of soft rock, clay, most } \\
\text { material }^{2}\end{array}$ & $\begin{array}{l}\text { Digging, dozing, ripping of hard } \text { rock }^{2} \\
\text { Object materials, blasted rock } \\
\text { Continuous use with engine at full throttle }^{2} \text { Little or } \\
\text { no idling or travel in reverse }\end{array}$ \\
\hline & $\begin{array}{l}0,10 \div 0,14 \mathrm{l} /(\mathrm{kW} \cdot \mathrm{h})^{1} \\
0,07 \div 0,11 \mathrm{l} /(\mathrm{kW} \cdot \mathrm{h})^{2}\end{array}$ & $\begin{array}{l}0,14 \div 0,18 \mathrm{l} /(\mathrm{kW} \cdot \mathrm{h})^{1} \\
0,11 \div 0,16 \mathrm{l} /(\mathrm{kW} \cdot \mathrm{h})^{2}\end{array}$ & $\begin{array}{c}0,18 \div 0,23 \mathrm{l} /(\mathrm{kW} \cdot \mathrm{h})^{1} \\
0,16 \div 0,20 \mathrm{l} /(\mathrm{kW} \cdot \mathrm{h})^{2}\end{array}$ \\
\hline \multirow[t]{2}{*}{ 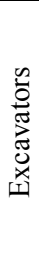 } & $\begin{array}{l}\text { Sandy loam, free flowing, low density } \\
\text { material. } \\
\text { Little travelling and little or no impact } \\
\text { Slope finishing, light material digging, } \\
\text { and other light-duty operation }{ }^{2}\end{array}$ & $\begin{array}{l}\text { Excavation and trenching in natural bed clay } \\
\text { soils }^{1} \\
\text { Some travelling and steady, full throttle } \\
\text { operation }^{1} \\
\text { Mainly excavating and loading }^{2} \\
\text { Breaker operation }^{2}\end{array}$ & $\begin{array}{l}\text { Continuous trenching or truck loading in rock or shot } \\
\text { rock soils }{ }^{1} \\
\text { Constant high load factor and high impact }{ }^{1} \\
\text { Using hammer, working in quarries }{ }^{1} \\
\text { Excavation of hard bank }^{2}\end{array}$ \\
\hline & $\begin{array}{l}0,05 \div 0,10(1 / \mathrm{kWh})^{1} \\
0,06 \div 0,09(1 / \mathrm{kWh})^{2}\end{array}$ & $\begin{array}{l}0,10 \div 0,15 \mathrm{l} /(\mathrm{kW} \cdot \mathrm{h})^{1} \\
0,09 \div 0,12 \mathrm{l} /(\mathrm{kW} \cdot \mathrm{h})^{2}\end{array}$ & $\begin{array}{l}0,15 \div 0,20 \mathrm{l} /(\mathrm{kW} \cdot \mathrm{h})^{1} \\
0,12 \div 0,20 \mathrm{l} /(\mathrm{kW} \cdot \mathrm{h})^{2}\end{array}$ \\
\hline \multirow[t]{2}{*}{ 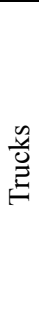 } & $\begin{array}{l}\text { Continuous operation at an average gross } \\
\text { weight less than recommended } \\
\text { No overloading, low load factor } \\
\text { High ratio of loading time to cycle time } \\
\text { Good haul road conditions }\end{array}$ & $\begin{array}{l}\text { Continuous operation at an average gross weight } \\
\text { approaching recommended } \\
\text { Minimal overloading. good haul roads }{ }^{1} \\
\text { Medium ratio of travelling time to cycle time }{ }^{2} \\
\text { Medium haul road conditions and grade }{ }^{2} \\
\text { Total resistance; Over } 2 \% \text { through } 10 \%^{2} \\
\text { medium load factor of truck }\end{array}$ & $\begin{array}{l}\text { Continuous operation at or above maximum } \\
\text { recommended gross weight }^{1} \\
\text { Overloading } \\
\text { Poor haul roads } \\
\text { High ratio of travelling time to cycle time } \\
\text { Severe haul road conditions and grade } \\
\text { Total resistance; } 10 \% \text { and above } \\
\text { Tough load factor of truck }\end{array}$ \\
\hline & $\begin{array}{l}0,05 \div 0,07 \mathrm{l} /(\mathrm{kW} \cdot \mathrm{h})^{1} \\
0,05 \div 0,07 \mathrm{l} /(\mathrm{kW} \cdot \mathrm{h})^{2}\end{array}$ & $\begin{array}{l}0,07 \div 0,10 \mathrm{l} /(\mathrm{kW} \cdot \mathrm{h})^{1} \\
0,07 \div 0,10 \mathrm{l} /(\mathrm{kW} \cdot \mathrm{h})^{2}\end{array}$ & $\begin{array}{c}0,10 \div 0,12 \mathrm{l} /(\mathrm{kW} \cdot \mathrm{h})^{1} \\
0,10 \div 0,13 \mathrm{l} /(\mathrm{kW} \cdot \mathrm{h})^{2}\end{array}$ \\
\hline \multirow[t]{2}{*}{ 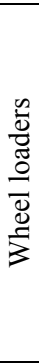 } & $\begin{array}{l}\text { Intermittent aggregate truck loading from } \\
\text { stockpile }^{1} \\
\text { Free flowing. low density materials }{ }^{1} \\
\text { Smooth surfaces for short distances with } \\
\text { minimal grades }^{1} \\
\text { Operation with substantial truck waiting }_{\text {time }^{2}} \\
\text { Considerable amount of idling }^{2}\end{array}$ & $\begin{array}{l}\text { Continuous truck loading from stockpile }{ }^{1} \\
\text { Low to medium density materials in properly } \\
\text { sized bucket } \\
\text { Normal surfaces with low to medium rolling } \\
\text { resistance and slight adverse grades }{ }^{1} \\
\text { Non-stop operation over a long distance }{ }^{2} \\
\text { Operation according to a basic loader cycle with } \\
\text { frequent idling }\end{array}$ & $\begin{array}{l}\text { Loading shot rock from a face } \\
\text { Steady loading from very tight banks }{ }^{1} \\
\text { High density materials with counterweighted } \\
\text { machine }^{1} \\
\text { Longer travel distances on poor surfaces with }^{\text {adverse grades }}{ }^{1} \\
\text { Bank excavation and loading } \\
\text { Loading of blasted rock }^{2} \\
\text { Non-stop operation according to a basic loader cycle }\end{array}$ \\
\hline & $\begin{array}{l}0,04 \div 0,08 \mathrm{l} /(\mathrm{kW} \cdot \mathrm{h})^{1} \\
0,07 \div 0,10 \mathrm{l} /(\mathrm{kW} \cdot \mathrm{h})^{2}\end{array}$ & $\begin{array}{l}0,08 \div 0,11 \mathrm{l} /(\mathrm{kW} \cdot \mathrm{h})^{1} \\
0,10 \div 0,13 \mathrm{l} /(\mathrm{kW} \cdot \mathrm{h})^{2}\end{array}$ & $\begin{array}{c}0,11 \div 0,14 \mathrm{l} /(\mathrm{kW} \cdot \mathrm{h})^{1} \\
0,13 \div 0,17 \mathrm{l} /(\mathrm{kW} \cdot \mathrm{h})^{2}\end{array}$ \\
\hline \multicolumn{4}{|c|}{1 - adopted from Caterpillar [6]; 2 - adopted from Komatsu [5] } \\
\hline
\end{tabular}

Table 6 Load-specific fuel consumption after Đukan et al. [9]

\begin{tabular}{|l|c|}
\hline & Load-specific fuel consumption $\mathrm{l} /(\mathrm{kW} \cdot \mathrm{h})$ \\
\hline Excavators & 0,28 \\
\hline Wheel loaders & 0,19 \\
\hline Bulldozers & 0,25 \\
\hline Trucks & 0,22 \\
\hline
\end{tabular}

Table 7 Load-specific fuel consumption after Gransberg et al. [10]

\begin{tabular}{|l|c|c|c|}
\hline \multirow{2}{*}{} & \multicolumn{3}{|c|}{$\begin{array}{c}\text { Load-specific fuel consumption } \\
\text { at operating conditions } 1 /(\mathrm{kW} \cdot \mathrm{h})\end{array}$} \\
\cline { 2 - 4 } & Favourable & Average & Unfavourable \\
\hline Wheel loader & $0,10 \div 0,12$ & $0,14 \div 0,18$ & $0,16 \div 0,24$ \\
\hline Bulldozer & $0,14 \div 0,17$ & $0,19 \div 0,20$ & $0,23 \div 0,24$ \\
\hline Truck & $0,09 \div 0,15$ & $0,12 \div 0,19$ & $0,15 \div 0,23$ \\
\hline
\end{tabular}

A recent research within EPA's NONROAD model for calculation of emissions includes a number of direct measurements of fuel consumption and determination of load factors for various equipment and engine types [11, 12]. The individual test results found in these sources, for the equipment of interest here, show that factors can vary significantly - from 0,34 to 0,7 for excavators, from 0,16 to 0,48 for wheel loaders and from 0,46 to 0,58 for bulldozers. In a larger scale the data on load factors for all equipment are averaged and put into three categories, 'high', 'low', and 'steady-state'. Within this categorization, excavators, bulldozers, off-highway trucks, and wheel loaders fall into 'high' category with the average factor of 0,59 . Drill rigs and crushing/processing plants are put into 'steady-state' category with the average value of 0,43 .

\section{$4 \quad$ Quarrying process and operating conditions}

Typical operations in quarrying of crushed stone first include overburden removal, if necessary. The excavation technique depends on deposit materials characteristics. Overburden commonly appears as the top layer of soil and humus or friable rock. Weak mechanical properties of these materials allow for usage of bulldozers and excavators for removal. Secondly, an underlying mineral raw material is excavated by drilling and blasting operations.

The following operation is transport of excavated rock material. Since most quarries are hillside type, gravitational transport, i.e. throwing from upper to lower benches, is used as the most economical method. This operation takes place until raw material reaches the first haulage way or pit bottom, where succeeding operations are continued.

The order of further operations depends on a specific quarrying system, but regularly includes the secondary reduction of oversized material, a transportation system and processing.

The secondary reduction is usually done using a hydraulic hammer, and rarely by blasting. Mainly because of safety, noise and discontinued production issues related to explosives. Load and haulage systems in small quarries of crushed stone are regularly composed of excavators or wheel loaders and rear dump trucks. Many quarries still process mineral raw material on fixed, i.e. stationary 
plants, but mobile crushing and screening is increasingly used in addition to stationary one, or even as the only processing equipment. Mobile equipment provides greater flexibility and savings in haulage expenses.

The specific mining company that provided the data on fuel consumption uses all the mentioned equipment, for quarrying of diabase and dolomite. Quarries are typical for crushed stone and so are the operating conditions described in the following text.

The bulldozer is almost exclusively used for gravitational transport of excavated overburden and mineral raw material. It mostly operates with loose material on horizontal benches and without any ripping. Its cycle composes of forming the drag prism during the larger part of trajectory, discharging full blade load over the bench crest and backwards return. This could be defined as light to average operating conditions.

Backhoe excavators are mostly utilized on excavation of top soil and friable rock sections, and loading of blasted rock material into mobile processing plants and trucks. This represents the average operating conditions for excavators, with transition to heavy if excavation of rock occurs. One excavator is an exception that frequently operates with hydraulic hammer, on secondary breaking of oversized material.

Wheel loaders and trucks perform typical operations for this type of equipment. Loaders are used for loading and short transport of loose and finer-granulated material, such as processed crushed rock. Both, loaders and trucks, operate on relatively stiff and well maintained surfaces with slight or no grades. This includes pit bottom and haulage roads. Operating conditions for this equipment can be considered as light.

The blasthole drill operates in diabase and dolomite on benches that are mostly $20 \mathrm{~m}$ in height and with the usual drill pattern of $2,7 \times 3 \mathrm{~m}$. It is equipped with DTH hammer and $90 \mathrm{~mm}$ drill bits.

Mobile crushing and screening plants are used for processing of multiple rock types and production of various aggregate fractions depending on market demands.

The mobile belt conveyor is used in addition to processing plants for deposition of outlet rock materials in order to achieve larger heaps.

\section{$5 \quad$ Load factors analysis}

Load factors were derived from the continuous, fiveyear period, data on fuel consumption of the main equipment used in quarrying process.

Averaged hourly fuel consumption, expressed in litres per hour, is converted into fuel mass using the usual fuel density of $0,85 \mathrm{~kg} / 1$ [13].

All the equipment is up to six years old and equipped with modern diesel engines. Thus, for specific fuel consumption of diesel engines, the value of 0,22 $\mathrm{kg} /(\mathrm{kW} \cdot \mathrm{h})$ is selected. To confirm this value, the relation from Fig. 1 was used. As rated engine power of equipment subjected to this research ranges from 28,8 to $370 \mathrm{~kW}$, selected value of $0,22 \mathrm{~kg} /(\mathrm{kW} \cdot \mathrm{h})$ is suitable.

Finally, empirical load factors for equipment were obtained by dividing hourly fuel consumption by rated engine power and selected specific fuel consumption. Tab. 8 presents input data and calculated results.

The average load factor for excavators amounts to 0,561 with a slight deviation between models. According to different sources this value belongs within the average operating conditions, which is also the case in these quarries. The exception is the light wheel excavator R200W-7 with the factor of 0,301 . This unit is very frequently used with the hydraulic hammer for reduction of the oversized rock material. It is possible that the hammer engages a lower portion of engine power compared to the excavation and loading operations. However, due to the fact that it is the only unit in this research, the general conclusion cannot be derived.

Wheel loaders have an average load factor of 0,273 and for trucks it amounts to 0,236. Deviation between models is negligible, especially for trucks. This equipment can be considered as the least engine-power demanding in the quarrying process. The reason for low load factors can be partially found in working cycles of this equipment, where half of the cycle is done without load (cargo). Good operating conditions in quarries, with well-maintained haulage roads and without steep grades, are favourable for low power demand. Same conditions belong into the light range according to other sources.

The only bulldozer used in this analysis has a load factor of 0,485 , which corresponds to light to average operating conditions according to other sources. Conditions in these specific quarries can be described as such, considering that the bulldozer is used in gravitational transport that includes moving of loose rock material on the horizontal benches, in one direction.

The mining company has one blasthole drill for which the calculated load factor amounts to 0,616 . As this is the only unit, it is difficult to say that the results are typical representative for this type of equipment. Besides, calculated factor represents an average value for drilling in two rock types, diabase and dolomite. Thus, it is not known if the factor differs when drilling is performed in different rock types.

Load factors for two jaw crushers deviate very slightly, and average to 0,467 . Cone crusher shows somewhat lower factor of 0,387 and that is why it is set aside from the crusher's average. The difference between jaw and cone crusher could be attributed to the crusher type, and probably also to different rock types that are processed.

Mobile screening plants show the largest deviation of load factors among the models, from 0,22 to 0,783 , with an average of 0,491 . The lowest factor is for the roller screen, while vibrating screens show generally higher factors, but with the significant deviation between the models. It can be assumed that the screen working principle affects the load factor, but is also influenced by constructional features like the number of screen decks, engine power and the number of belt conveyors.

Mobile belt conveyor has the load factor of 0,52 . Constructional features could have an important influence on it, similarly to screening plants. It is the only unit of that type used in the research, thus no span of the factor can be derived. 
Table 8 Data on fuel consumption and calculated load factors

\begin{tabular}{|c|c|c|c|c|c|}
\hline Manufacturer and model & $\begin{array}{l}\text { Rated power } \\
\quad(\mathrm{kW})\end{array}$ & $\begin{array}{l}\text { Fuel consumption } \\
(1 / \mathrm{h})\end{array}$ & $\begin{array}{l}\text { Load-specific fuel } \\
\text { consumption } \\
1 /(\mathrm{kW} \cdot \mathrm{h})\end{array}$ & $\begin{array}{l}\text { Calculated } \\
\text { load factor }\end{array}$ & $\begin{array}{l}\text { Average } \\
\text { load } \\
\text { factor }\end{array}$ \\
\hline \multicolumn{6}{|l|}{ Excavators } \\
\hline Hyundai R 200W - 7 (hammer) & 114 & 8,87 & 0,078 & 0,301 & 0,30 \\
\hline Liebher R 944 C HD-S Litronic & 190 & 32,52 & 0,171 & 0,661 & \multirow{5}{*}{0,56} \\
\hline Liebher R 944 B HD-S Litronic & 180 & 23,96 & 0,133 & 0,514 & \\
\hline Liebher R 934 C HD-S Litronic & 150 & 21,96 & 0,146 & 0,566 & \\
\hline Liebher R 934 B HD-S Litronic & 145 & 17,62 & 0,122 & 0,469 & \\
\hline Liebher R 914 B Litronic & 112 & 17,29 & 0,154 & 0,596 & \\
\hline \multicolumn{6}{|l|}{ Wheel loaders } \\
\hline Caterpillar $966 \mathrm{H}$ & 213 & 15,07 & 0,071 & 0,273 & \multirow{6}{*}{0,27} \\
\hline Caterpillar $966 \mathrm{H}$ & 213 & 14,59 & 0,068 & 0,265 & \\
\hline Liebherr L 576 & 205 & 16,43 & 0,080 & 0,310 & \\
\hline Liebherr L 576 & 205 & 14,50 & 0,071 & 0,273 & \\
\hline Liebherr L 576 & 205 & 13,96 & 0,068 & 0,263 & \\
\hline Liebherr 574 & 195 & 12,76 & 0,065 & 0,253 & \\
\hline \multicolumn{6}{|l|}{ Trucks } \\
\hline Bell B40D & 308 & 18,67 & 0,061 & 0,234 & \multirow{3}{*}{0,23} \\
\hline Bell B40D & 308 & 18,78 & 0,061 & 0,236 & \\
\hline Terex TR45 & 370 & 22,74 & 0,061 & 0,237 & \\
\hline \multicolumn{6}{|l|}{ Bulldozer } \\
\hline Komatsu D155 AX - 6 & 264 & 33,16 & 0,126 & 0,485 & 0,48 \\
\hline \multicolumn{6}{|l|}{ Blasthole drill } \\
\hline Bohler BPI 155 & 125 & 19,96 & 0,160 & 0,616 & 0,61 \\
\hline \multicolumn{6}{|l|}{ Mobile crushing plants } \\
\hline Locotrack LT $105 \mathrm{~S}$ (jaw) & 224 & 27,98 & 0,125 & 0,483 & \multirow{2}{*}{0,46} \\
\hline Locotrack LT 110S (jaw) & 310 & 36,26 & 0,117 & 0,452 & \\
\hline Locotrack LT $200 \mathrm{HP}$ (cone) & 310 & 31,04 & 0,100 & 0,387 & 0,38 \\
\hline \multicolumn{6}{|l|}{ Mobile screening plants } \\
\hline Finly 393 (vibrating) & 69 & 6,00 & 0,087 & 0,336 & \multirow{4}{*}{0,49} \\
\hline Chieftain 2100 (vibrating) & 74 & 15,00 & 0,203 & 0,783 & \\
\hline Posch FLEX RO - RO (roller) & 149 & 8,49 & 0,057 & 0,220 & \\
\hline Warrior 1800 (vibrating) & 74 & 12,00 & 0,162 & 0,627 & \\
\hline \multicolumn{6}{|l|}{ Mobile belt conveyor } \\
\hline TELESTACK TC 421 & 28,8 & 3,90 & 0,135 & 0,523 & 0,52 \\
\hline
\end{tabular}

\section{Data comparison}

The above mentioned sources provide the data which can be classified into three types: hourly fuel consumption expressed in $1 / h$, load-specific fuel consumption expressed in $1 /(\mathrm{kW} \cdot \mathrm{h})$, and engine load factor. In order to compare these different types of data to the empirical ones, all values were converted to load factors. Afore stated values for fuel density of $0,85 \mathrm{~kg} / \mathrm{l}$ and the specific fuel consumption of $0,22 \mathrm{~kg} /(\mathrm{kW} \cdot \mathrm{h})$ were used. Different data types were converted as presented in the following table:

Table 9 Conversions to load factor

\begin{tabular}{|c|c|c|}
\hline Input data & Conversion & Result \\
\hline $\begin{array}{c}\text { Hourly fuel } \\
\text { consumption }\end{array}$ & $\begin{array}{c}\text { Load } \\
\text { factor }\end{array}$ \\
\hline $\begin{array}{c}\text { Load-specific fuel } \\
\text { consumption }\end{array}$ & $\frac{X}{0,22} \cdot 0,85$ & $\begin{array}{c}\text { Load } \\
\text { factor }\end{array}$ \\
\hline Load factor & no conversion & $\begin{array}{c}\text { Load } \\
\text { factor }\end{array}$ \\
\hline
\end{tabular}

The results are presented within diagram in Fig. 2, where load factors from different sources are grouped by the equipment type and classified by operating conditions.

Diagram contains empirical data points compared to other sources. Depending on the source, factors are presented either as single point that represent one operating condition, or as lines that represent ranges of the same (low, medium and high, or their equivalents). Factors are marked as unclassified in case those conditions are not specified, or there is no basis to define them.

The data for the common equipment i.e. bulldozers, excavators, wheel loaders and trucks are specified in most sources. The comparison shows that the mean empirical load factors fall within the same range for trucks and wheel loaders, where the description of operating conditions $[1,5,6]$ corresponds to the operations in the specific quarries subjected to this research. For excavators and the bulldozer they fall into the same range or are slightly shifted into the adjacent range. The sources without details on operating conditions generally show either higher values of load factor, compared to empirical data, or an inadequate span of values across operating conditions. With the exception of favourable conditions for trucks according to Chitkara [8] and for bulldozers according to Day [7].

The hydraulic breaker represents the operating condition of an excavator, but it is separated for clarity. According to the equipment manuals $[5,6]$ an excavator using a breaker can fall into the medium or high range of conditions. Still, the empirical data point falls below these values. 


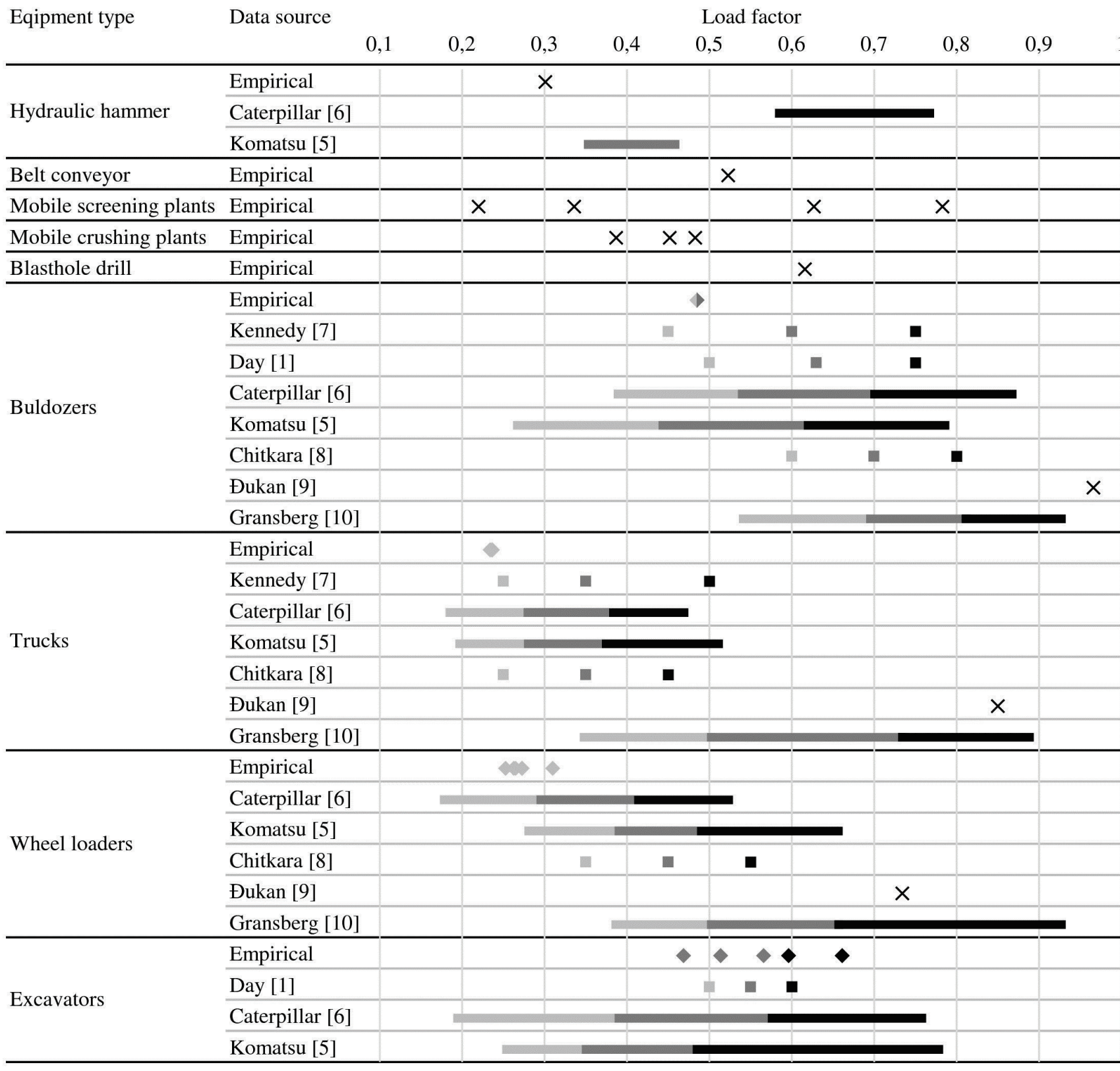

Classification of operating conditions:

Figure 2 Comparison of load factors

\section{Conclusions}

Engine load factors of main equipment used in quarrying of crushed stone are calculated based on the five-year data on fuel consumption. The obtained empirical values can be used in estimation of fuel consumption if similar operating conditions exist in quarries and other surface pits. This applies especially to trucks with the mean value of 0,24 and wheel loaders with the value of 0,27 , due to the low deviation from mean values and a good correlation to the most other sources.

The empirical load factors for excavators and mobile processing plants are more scattered around the mean value, but their span in quarrying of crushed stone is evident. They range from 0,47 to 0,66 for excavators and from 0,39 to 0,48 for mobile processing plants.

Load factors for other equipment can be used as approximate, since there are not enough data to achieve a greater level of certainty. The data for only one bulldozer, blasthole drill, hydraulic breaker and belt conveyor unit are used in this research. The bulldozer, with factor value of 0,48 is an exception, because it shows a good correlation to several other sources.

The excavator using a hydraulic breaker has a load factor of 0,3 , which is much lower than the values stated in literature $[5,6]$. The specific excavator is a wheel type. Therefore, it is possible that the low load factor is caused by using the breaker. Lower rolling resistance, compared to the crawler type, could also have some influence.

Mobile screening plants tend to have a very wide span of load factors, from 0,22 to 0,78 . This could be caused by a number of factors, including constructional features of the plant and mineral raw material properties. For this reason it is difficult to define common operating conditions for this type of equipment. 
The belt conveyor and blasthole drill also lack the definition of operating conditions. Due to the insufficient data it is not possible to conclude how much would the load factor differ with the operation in other mineral raw materials, or with different constructional features of equipment?

In the absence of empirical data on fuel consumption, both load factors and load-specific fuel consumption for the known operating conditions and equipment type can be used for estimation. The use of load factors is more versatile because they remain constant and it is possible to account for changes in engine efficiency and fuel density.

The presented load factors and consumptions based on Komatsu and Caterpillar manuals correlate most closely with the empirical data for the majority of quarrying equipment. It can be assumed that they provide the most accurate estimation in case of different operating conditions.

\section{Acknowledgments}

The authors wish to thank the mining company IGM Radlovac for the provided data on fuel consumption.

\section{References}

[1] Kennedy, B. Surface Mining. / Society for Mining Metallurgy \& Exploration, Baltimore, 1990.

[2] Kecojevic, V.; Komljenovic, D. Haul Truck Fuel Consumption and $\mathrm{CO}_{2}$ Emission under Various Engine Load Conditions. // Mining Engineering. 62. 12(2010). pp. 44-48.

[3] Runge. C. I. Mining Economics and Strategy. / Society for Mining Metallurgy \& Exploration, Littleton, 1998.

[4] Stefanović. A. N. Građevinske mašine (Machines Used in Construction), Građevinska knjiga, Beograd, 1980.

[5] Komatsu. Specification \& Application Handbook - edition 30, Komatsu Ltd, Tokyo, 2009.

[6] Caterpillar. Caterpillar Performance Handbook - edition 40, Caterpillar Inc, Peoria, 2010.

[8] Chitkara, K. K. Construction Project Management, Tata McGraw-Hill Publishing Company Limited, New Delhi, 1998.

[7] Day, D. A.; Benjamin, B. H. N. Construction Equipment Guide, Wiley and Sons, New York, 1991.

[9] Đukan, P.; Bosanac, B.; Mrvoš, Lj.; Paskojević, A. Strojevi $\mathrm{u}$ građevinarstvu (Machines in Civil Engineering). Građevinar, Zagreb, 1991.

[10] Gransberg, D. D.; Popecu, C. M.; Ryan, C. R. Construction Equipment Management for Engineers, Estimators and Owners. Taylor \& Francis, Boca Raton, 2006.

[11] EPA. Median Life, Annual Activity and Load Factor Values for Non-road Engine Emissions Modeling. US Environmental Protection Agency. Report no. NR-005d.

[12] Sabisch, M.; Kishan, S.; DeFries, T. et al. Development of Emission Factors, Load Factors, Duty Cycles and Activity Estimates from Nonroad PEMS study. // CE-CERT PEMS Conference / Riverside. 2013.

[13] INA. Katalog goriva (Fuel Catalog) - izdanje 07, INA industrija nafte, Zagreb, 2013.

\section{Authors' addresses}

Mario Klanfar, assistant

University of Zagreb

Faculty of Mining, Geology and Petroleum Engineering Pierottijeva 6, 10000 Zagreb, Croatia

E-mail: mario.klanfar@rgn.hr

\section{Tomislav Korman, assistant}

University of Zagreb

Faculty of Mining, Geology and Petroleum Engineering

Pierottijeva 6, 10000 Zagreb, Croatia

E-mail: tomislav.korman@rgn.hr

Trpimir Kujundžić, assoc. prof.

University of Zagreb

Faculty of Mining, Geology and Petroleum Engineering

Pierottijeva 6, 10000 Zagreb, Croatia

E-mail: trpimir.kujundzic@rgn.hr 